\title{
Darwinisme en die bakterieë
}

\author{
J.N. Coetzee \\ Charlesstraat 61, Baileys Muckleneuk, Pretoria 0181
}

Ontrang 3 Maart 1992; aanvaar 24 April 1992

\section{UITTREKSEL}

Die ontwikkelingsgang van die evolusieleer tydens die eeuwisseling het die vroeë bakteriologie skaars geraak; die redes vir die destydse gebrek aan 'n betroubare filogenetiese indeling van bakterië word in hierdie artikel aangebied. Oorsake vir aanvaarding van die leer van die oorerflikheid van verworwe eienskappe, om sodoende die wonderlike aanwendbaarheid van bevolkings bakterieë te verklaar, word ondersoek. Die geloofwaardigheid van hierdie stelling het tot minstens die middel-veertigerjare behoue gebly. Eksperimentele waarnemings het toe daarop begin dui dat aangepaste mutante alleenlik as gevolg van lukraak mutasies verskyn wat eers later op die fenotipiese vlak gekeur word. Die geleidelike a anvaarding van hierdie begrip het bakteriologie in pas met die heersende Neo-Darwinistiese siening gebring - 'n bloeitydperk vir bakteriese genetika is ontketen wat tot die biologie in sy totaliteit uitgekring het. In die huidige verband was ondersoeke op die molekulêre sistematiek besonder vrugbaar: deur volgordebepalings op onderdele van sekere makromolekules te doen, is 'n magdom van data bekom wat tot historiese inligting verwerk kon word. Hierdie proses kan letterlik met 'n molekulêre genealogie vergelyk word en sodoende is 'n filogenetiese indeling van bakterië (en terloops alle lewende vorms) daargestel. Sedert die middel-vyftigerjare, maar veral gedurende die afgelope paar jaar, het 'n rits eksperimentele gegewens verskyn wat nie strook met die Neo-Darwinistiese begrip van mutasie en seleksie wat onafhanklik van mekaar sou wees nie. 'n Reeks mutasies is beskryf-gerigte mutasies - wat teen 'n hoër waarskynlikheid voorkom wanneer hulle gunstig vir oorlewing is as wanneer hulle neutraal blyk te wees. Hierdie bevindings het aangedui hoe wankelrig geloof in die lukraak aard van mutasie regtig was. Neo-Darwinisme is 'n teorie wat, uit die wese van sy ontstaan minstens ' $n$ halfeeu gelede, baie plooibaar is. Die voorstanders van die teorie moes hierdie eienskap telkemale gebruik om die lewensvatbaarheid daarvan te behou. Indien gerigte mutasies se bestaan verder bewaarheid word, is Neo-Darwinistiese opvattings hopelik nog ruim genoeg om ook hierdie nuutontdekte gedrag van genome te akkommodeer. Só 'n sintese kan die teorie van evolusie verder verryk.

\section{ABSTRACT}

\section{Darwinism and bacteria}

The course of development of the theory of evolution at the turn of the century hardly influenced early bacteriology, and reasons for the lack of a reliable phylogenetic classification of bacteria at the time are presented. Causes for adoption of the doctrine of the inheritance of acquired characteristics in bacteria, in an effort to explain the wonderful adaptability of bacterial populations, are examined. This doctrine prevailed until at least the mid-forties. Experimental results then started appearing which indicated that adaptive mutants arose as a result of random mutations which were only subsequently selected at phenotypic level. The gradual acceptance of this view brought bacteriology in line with Neo-Darwinian thought. It led to a golden age of bacterial genetics the principles of which eventually influenced biology in its entirety. In the present context, investigations along the lines of molecular systematics were particularly fruitful: sequencing the components of certain macromolecules exposed a wealth of data that could be processed to yield historical information. This process can literally be equated with an analysis of molecular genealogy and resulted in a phylogenetic arrangement of bacteria and, incidentally, all other forms of life. Since the mid-fifties, but especially during the past few years, a series of experimental observations have appeared that have cast doubt on the Neo-Darwinian belief that mutation and selection are independent processes. Mutations-directed mutations-were described that occured with a greater probability when advantageous for survival than when neutral. These findings revealed how insecure belief in the randomness of mutations really was. Neo-Darwinism is a theory which, from the very nature of its origins more than half a century ago, tends to be pliable. The proponents of the theory have repeatedly employed this property in an effort to retain its viability. In the event of the claims regarding directed mutations being proved substantially correct, it is hoped that Neo-Darwinian concepts will be broad enough to accommodate this newly discovered behaviour of genomes. The resulting synthesis could further enrich the theory of evolution.

\section{VOOR 1943}

Ondanks begrip vir die rol wat kansmutasie met genetiese variasie by diere speel, het bakterioloë deur die jare ${ }^{1-3}$ eenvoudig aanvaar dat wysigings in kwekings van bakteriee na byvoorbeeld bestandheid teen antibakteriese middels, die gevolg van 'n direkte werking van die agens was. Die middel sou, op een of ander direkte wyse, ${ }^{4}$ die bevolking kon beinvloed om 'n oorerflike aanwending tot die nuwe omstandighede te tref. Hierdie siening is op aspekte van die eerste konsekwente teorie van evolusie gegrond wat in 1809 deur die Franse natuurkundige, Jean-Baptiste de Lamarck, voorgestel is. ${ }^{5}$ Onder andere het hy die heersende mening van die tyd duidelik in sy tweede wet, vir die verklaring van aanpassing by diere, gestel: alles wat die natuur indiwidue laat bekom of verloor as gevolg van langdurige blootstelling aan die invloed van die omgewing, aan die nageslag besorg word. ${ }^{6}$ Die benaming, Lamarckisme, word deesdae amper uitsluitlik aan hierdie stelling van die oorerflikheid van verworwe eienskappe gekoppel. 
Dié mening oor bakterieë is gerugsteun deur die geweldige plastisiteit wat bakteriese kwekings openbaar - wanneer 'n kultuur aan 'n ongunstige omgewing blootgestel word, mag dit baie gou verander om stabiel by die nuwe omstandighede aan te pas. ${ }^{7}$ Die wortel van die onkunde, wat minstens tot diep in die jare veertig geheers het, was die onvermoë om genetiese variasie tussen enkele bakteriese selle te bespeur sonder om seleksie op die hele bevolking toe te pas. Dus was dit nooit duidelik of voorafgaande reeds bestande genetiese variante teen byvoorbeeld ' $n$ antibiotikum, geselekteer word, of dat die antibiotikum self, op een of ander wyse, vir die geskikte oorerflike wysiging verantwoordelik was nie. ${ }^{8}$ Dit is verbasend dat met hierdie opvatting vanaf die einde van die laaste eeu tot diep in die vyftigerjare volhard is. Juis gedurende hierdie tydperk ${ }^{2}$ was daar pogings, veral van mikrobioloë van die Nederlandse skool onder leiding van Beijerinck, Kluyver en later $\mathrm{V}$ an Niel, om die natuurlike verwantskappe tussen bakterieë te ontrafel. Hierdie periode het ook die ontstaan van Neo-Darwinisme gelewer. NeoDarwinisme, of die moderne sintese, of die sintetiese teorie van evolusie soos dit ook bekend staan," 12 het gedurende die laat dertiger- en die veertigerjare vanuit Darwin se teorie gevloei as gevolg van veral twee wendings: die skrapping van enige oorblywende sweempie Lamarckisme, en die vestiging van genetika, veral eers bevolkingsgenetika, as integrale deel van die evolusieteorie, om sodoende Darwin se gedagtes te vestig en uit te bou. Die grondslag van die nuwe opvatting was steeds Darwinisties: aanpassing by die omgewing wat deur lukraak alleliese vervanging in kiemlynselle bevorder word, met natuurlike seleksie as dryfkrag. Daar bestaan 'n mening ${ }^{13}$ dat die benamings van die huidige teorie neig om ingewikkeldhede te oorbeklemtoon en dat teruggekeer moet word na die blote naam Darwin.

\section{DIE LURIA-DELBRÜCK-ERA}

Die eerste klinkklare eksperimentele bewys dat bakterieë ook die Neo-Darwinistiese siening oor aanwendingsmutante volg, is deur Luria en Delbrück in 1943 gelewer. ${ }^{14}$ Met hierdie elegante werk wat moderne bakteriese genetika en 'n heel nuwe siening van bakterieë ingelui het, kon die twee statisties bewys dat bakteriofaagbestande mutante, teenwoordig in logaritmies groeiende bevolkings Escherichia coli (kyk 6), spontaan ontstaan voor blootstelling aan bakteriofaag - die vooraanpassingsmutante van Cavalli-Sforza en Lederberg. ${ }^{15}$ Bevindings was duidelik gestel: bakteriofaagbestande Inutante van E.coli ontstaan op 'n stochastiese wyse en word dan op die fenotipiese vlak gekeur - ware neo-Darwinisme! Die bevindings van hierdie sogenoemde wissel-eksperimente en ander, ${ }^{15,16}$ wat weer eens die werklikheid van sulke mutante bewys het, is deur die meeste genetici aanvaar as hoegenaamd nie versoenbaar met vorige stellings wat wou hê dat die bakterieë se voorouers bakteriofaagbestandheid (of ander eienskappe) deur indiwiduele Lamarckistiese strewe ontwikkel nie. Nogtans het die bevindings van die eksperimente sterk teenkanting van veral Hinshelwood, die destydse president van die Royal Society of London, en medewerkers uitgelok. ${ }^{17,}{ }^{20}$ Hulle het op sekere moontlike tegniese tekortkominge van Luria en Delbrück se eksperimentele opset gewys en beweer dat alle bakterieë in 'n kweking oorerflik bestand kan raak (teen byvoorbeeld antibiotika of bakteriofaag) deur bloot 'n fisiologiese aanwendingsmeganisme. Die feit dat dit nie deurentyd gebeur nie, word aan die verskillende fenotipes wat in 'n bevolking bakterie heers, toegeskryf - sommige fenotipes kan glo nie betyds die nodige aanpassings tref nie en word dan deur die keuringsagent uitgeken. Die argumente (en eksperimente) van Hinshelwood het nie veel byval gevind nie, deels omrede sy gebruik van vae begrippe, die feit dat ander werkers bewys het dat heelwat van sy sogenoemde aangepaste variante wel bestande mutante was en omdat hy nooit herkombinasieproewe gebruik het om die moont like genetiese oorsprong van sy aangepaste variante uit te skakel nie. ${ }^{15}$ Nogtans was daar'n aantal bioloë (veral bakterioloë) wat die een of ander gekunstelde weergawe van Hinshelhood se verklarings bly koester het, en wat Luria in die laat veertigerjare genoop het om die heersende toestand in bakteriologie as die laaste vesting van Lamarckisme te beskryf. ${ }^{21}$

\section{UITEINDELIK: 'N NATUURLIKE RANGSKIKKING VAN IEWENDE WESENS}

Metazoa en metaphyta beskik oor 'n komplekse morfologie en 'n uitvoerige fossielgeskiedenis. Hierdie eienskappe het gelei tot die ontrafeling van uitgebreide patrone van evolusie, wat in hulle filogenetiese taksonomieë weerspieël ${ }^{22}$ is. Daarenteen is die morfologie en baie ander eienskappe van bakterieë en hulle fossiele $\mathrm{e}^{23-25}$ ieder te eenvoudig of bloot te onverklaarbaar om as grondslag vir'n natuurlike indeling te dien.22

Dit is eenvoudig nie moontlik om te besluit watter end van 'n fisiologiese of morfologiese reeks eienskappe as primitief of afgelei beskou moet word nie, ${ }^{26,27}$ gevolglik is 'n reeks uiteenlopende indelings van bakterieë voorgestel. Hierdie indelings het gewissel van 'n indeling gegrond op vergelykende fisiologie wat deur Orla Jensen in 1909 voorgestel is, tot die 1936-sisteem van Kluyver en Van Niel wat vergelykende morfologie as maatstaf gebruik het. ${ }^{29}$ Selfs Van Niel, aanvanklik 'n leier met pogings om 'n bakteriese filogenie te ontrafel, het in 1946, skynbaar uit frustrasie en bloot om bakterieë te identifiseer, 'n deterministiese klassifikasie voorgestel..$^{30}$ Een so 'n rangskikking - Bergey's Manual of determinative Bacteriology - is onder voogdyskap van die invloedryke American Society of Bacteriologists, in 1923 uitgegee. Dit was wêreldwyd aanvaar as die standaardtaksonomie van bakterieë en het in 1974 selfs 'n agste uitgawe beleef ( $k y k 26)$. Tot en met die sewende uitgawe van 1957 was hierdie indeling ("Bergey") filogeneties van aard, gegrond op vergelykende morfologie en fisiologie (kyk bo) en geskoei op dié van diere en plante! Die indeling, met sy formele kategorieë en gebruik van 'n tweeledige LatynsGriekse terminologie op 'n tydstip toe selfs genealogiese verwantskappe van bakterieë nie bepaal kon word nie, ${ }^{26}$ word nou as bedrieglik outoritêr beskou.

Hierdie onbevredigende toestand het in die middel van hierdie eeu aanleiding gegee tot 'n periode van gebeusel waar die evolusie van bakterieë min aandag geniet het, ${ }^{2,3} \mathrm{en}$ die 1974-uitgawe van bogenoemde boek het uiteindelik (en tot groot verligting van baie bioloë) filogenie heeltemal ter syde gestel en bakterieë op 'n kunsmatige wyse ingedeel, slegs vir doeleindes van herkenning en identifikasie. ${ }^{26}$ Numeriese taksonomie het 'n verskyning in die laatvyftigerjare gemaak, ${ }^{31}$ maar fenetiese ooreenkoms is bepaald nie die benadering om te gebruik om filogenetiese verwantskappe uit te pluis nie. ${ }^{26}$ 
Bakteriologie was in 'n fase waar Darwin en voorgangers ${ }^{32}$ se blink gedagtes van evolusie deur natuurlike keuring, buite rekening gehou was. Die versuim om evolusionêre begrippe in die struktuur van bakteriologie in te voer, het nadelige gevolge vir biologie in sy geheel ingehou: die aarde bestaan vir 4,5 miljoen jaar ${ }^{33}$ en die vroegste mikroörganisme-fossiele dateer 3,1-3,5 miljoen jaar terug. ${ }^{22,25,34}$ Laasgenoemde se evolusionêre omvang dek dus 'n groot gedeelte van die aarde se geskiedenis en oortref die van eukariote met wie se evolusie bakterieë 'n belangrike rol gespeel het. 22, 24, 35-38 Hierdie uiters onbevredigende toestand is sedert 1965 dramaties aan die verbeter. In daardie jaar het Zuckerkandl en Pauling beweer dat 'n magdom van historiese inligting wat in sekere makromolekules opgesluit is, toeganklik gemaak kan word deur die volgordes van onderdele (byvoorbeeld aminosure of nukleotides) van die molekules, afkomstig van verskillende organisme, te vergelyk. ${ }^{39}$ Die nodige tegnieke van molekulêre sistematiek van bakterieë is veral deur Carl Woese $e^{2,35,36,40,41}$ ontwerp en onder sy leiding was die stellings van Zuckerkandl en Pauling tot ' $n$ heel nuwe begrip van evolusie van die ganse biota gevoer. ${ }^{23}$ Die fossielregister, wat vir metazoa gebruik word, word nou letterlik deur hierdie tegnieke vervang. ${ }^{{ }^{0}}$ Só het Woese en medewerkers bepaal dat molekulêre volgordes van ribosomale RNA evolusionêre verwantskappe oopvlek op 'n wyse, en tot ' $n$ mate, wat vir die klassieke fenotipiese kriteria, of selfs vergelykende studies van molekulêre funksies, onmoontlik is. ${ }^{22}$ Nou is dit moontlik om 'n natuurlike (filogenetiese) indeling van bakterieë te doen ${ }^{2,36,42}$ deur gebruik te maak van inligting wat in nukleotiedvolgordes van 16SRNA-molekules vervat is. ${ }^{40}$ Selfs die 1984-uitgawe van Bergey maak melding van 'n nuwe natuurlike indeling en word sekere wysigings aan sy bestaande taksonomie aangebring. ${ }^{43}$

Die ontledings, wat op 'n molekulêre genealogiese analise neerkom, het dit ook moontlik gemaak om die evolusie van eukariote na te gaan en tans mag alle lewe op aarde in 'n natuurlike sisteem, bestaande uit drie domeine, Archaea, Bakteria en Eucarya, ingedeel word. ${ }^{22}$

\section{ONTSTELLENDE FEITE VIR ENGE NEO- DARWINISTE}

Dit word nou al hoe meer besef dat DNA wel deur faktore van die omgewing beïnvloed mag word om aangewende genetiese veranderings - na-aanpassings - te laat ontstaan. ${ }^{15}$ Aanduidings van sulke aanpassings word sporadies sedert die middel-vyftigerjare aangeteken. ${ }^{+4.45}$ Ondervinding dui geleidelik daarop dat die voortstelling van 'n geen as iets onveranderlik gedurende oorerflike transmissie, ${ }^{\text {th }}$ alhoewel dit 'n doel met die ontwaking van Mendelse genetika gedien het, te rigied is. Só word die uitsny van DNA-stroke, deur 'n omgewingsgeïnduseerde DNA-herkombinase, aanvaar om 'n rol te speel met terminale ontwikkeling van heterosiste by sianobakterieë, ${ }^{47}$ asook by die spoorvorming van Bacillus subtilis ${ }^{48,49}$ Ook mag die inlas van bakteriofaag-kernmateriaal in die chromosoom van 'n bakterium, lisogenisasie, dien om die bakterium teen 'n daaropvolgende litiese aanval van die virus te vrywaar. ${ }^{50}$ Dit is ' $n$ voorbeeld van 'n genetiese aanwending wat spesifiek deur die omgewing (die bakteriofaag) geïnduseer word - 'n na-aanpassing of gerigte mutasie. ${ }^{20}$ Nog 'n verskynsel wat as gerigte mutasie beskou kan word, is die spesifieke bevryding van bakteriee van sekere plasmiede deur eersgenoemde met akridienkleurstowwe of ander chemiese of fisiese middels te behandel. ${ }^{51}$ Ander voorbeelde wat op die genoom se veranderlikheid en omgewingsgevoeligheid dui, is mutasies gekoppel aan die inlas van beweeglike genetiese elemente, die sogenoemde SOS-respons - genetiese onstabiliteit wat op omgewingsveroorsaakte DNA-beskadiging volg $\mathrm{g}^{54,55}$ - en selfs die juistheid waarmee mutasies deesdae in spesifieke gene van bakterieë aangebring mag word. ${ }^{56}$

Die ontogenieproses in veelsellige diere en plante, waar 'n sel eienskappe in 'n bepaalde omgewing opdoen wat dan getrou na dogterselle deurgevoer word, dien ook as voorbeeld van omgewingsgeïnduseerde veranderings wal oorerflik ${ }^{13,57}$ is. Die oorerflike veranderings in morfologie en DNAinhoud van veral vlasplante na blootstelling van die saad aan omgewingsdruk van verskeie soorte, is 'n bevinding van die vroeë sestigerjare (kyk 58) en is 'n aanduiding van die omvang van die probleem van omgewingsgeïnduseerde genetiese veranderings.

Sedert die middel-tagtigerjare is daar sekere eksperimente op $E$. coli uitgevoer waarvan die resultate ook nie met 'n Neo-Darwinistiese opvatting strook nie. Hierdie eksperimente het ook gedien om vorige bevindings (byvoorbeeld dié wat vroeër genoem is) wat weens hulle moontlike onversoenbaarheid met die behoudendheid van laasgenoemde teorie opsy gestoot was, weer in die kollig te plaas. Die eksperimente van Shapiro, ${ }^{59}$ Cairns $^{(6)}$ en Hall $^{61}$ is op stasionêre fase metaboliserende kwekings van verskillende glikosidase-gebrekkige $E$. coli, in teenwoordigheid van laktose of salisien, uitgevoer ${ }^{20}$ Hulle beskryf die voorkoms van 'n reeks mutasies wat die selle nou in staat stel om laktose te metaboliseer. Die mutasies is van uiteenlopende aard, maar vind teen 'n hoër waarskynlikheid plaas wanneer hulle gunstig vir oorlewing is as wanneer hul aanpassingsneutraal blyk te wees - sogenaamde gerigte ${ }^{60}$ of na-aanwendingsmutasies. ${ }^{15}$ Met 'n verdere eksperiment ${ }^{62}$ daag Hall die gevestigde mening nog verder uit: die opset hier is dat twee onafhanklike mutasies vir bakterieë nodig sou wees om by ' $n$ bepaalde omgewing aan te pas. Geeneen van die twee kan alleen 'n aanpassingsvoordeel bied nie. Nogtans, in die teenwoordigheid van seleksie, vind die dubbelmutasie plaas teen frekwensies baie hoër as wat verwag sou word uit die produk van afsonderlike mutasiefrekwensies. Op een of ander wyse word die eerste mutasie geprikkel om teen 'n hoër frekwensie te geskied, alhoewel dit op sigself skynbaar geen voordeel in die selektiewe omgewing bied nie. Hall noem die moontlikheid van vooruitlopende of verwagtende evolusie - inderdaad 'n heterodokse siening ${ }^{63}$ - amper ' $n$ kettery. ${ }^{6}$ Benson ${ }^{64}$ het sedertdien, met gebruik van nog ' $n$ ander sisteem van dieselfde organisme, ook tot die gevolgtrekking gekom dat bakterieè 'n vermoë besit om spesifieke gebreke te bespeur en dan mutasies só te rig dat die gebrek oorkom word.

Die gunstige aangewende eienskappe wat gerigte mutasies teweeg bring, is natuurlik oorerflik, maar strook nie juis met die tradisionele mening van Lamarckisme nie. 5, 6, 65 Laasgenoemde het, in sy eerste wet (voor Weismann die versperring tussen kiemlyn en soma by diere beskryf het, voor die chemiese grondslag van oorerflikheid ontdek is en voor ' $n$ onderskeid tussen genotipe en fenotipe getref is) 
beweer dat oorerflike morfologiese aanpassings op omgewingsdruk as gevolg van volgehoue gebruik (of onbruik) van organe ontstaan.

Bogenoemde eksperimenteerders beklemtoon dit dat alle mutasies in bakterieë nie noodwendig gerig is nie, maar dat sommige vorige eksperimentele uitslae (veral dié van Luria en Delbrück $)^{1+}$ wat op 'n lukraak verspreiding van mutasies dui, ondoelmatig veralgemeen is. Hulle wys daarop dat die meeste vorige eksperimente op logaritmies groeiende bakterieë uitgevoer is. Gevolglik was mutasiefrekwensies soos konstantes behandel wat aan selverdeling (generasies) gekoppel is wat net eienskappe van die genoom weerspieël.o. ${ }^{61}$ Die werkers beklemtoon dat omstandighede wat bakterieë logaritmies in getalle laat toeneem, selde in die natuur voorkom: die moontlikheid dat mutasiefrekwensies hoogs veranderlik en onderworpe is aan ander sellulêre prosesse en omgewingswysigings, word dikwels verontagsaam. ${ }^{6 /}$

Die navorsers is huiwerig om verklarings vir hulle bewerings van gerigte mutasies te bied juis omdat min bekend is oor die huishouding van selle wat hongersnood ly. ${ }^{45}$ Shapiro" ${ }^{54}$ en Hall $^{6 /}$ stel die moontlikheid van terugvoermeganismes wat die waarskynlikheid van gerigte mutasies, ten tye van omgewingsdruk, beheer. So 'n meganisme behoort veral te geld met organismes soos bakterieë wat nie 'n skeiding tussen soma en kiemlyn tref nie en sodoende alle inligting, met die volgende verdeelsessie, aan die nageslag besorg. ${ }^{8}$ Cairns $^{\left({ }^{()}\right)}$is ' $n$ bietjie meer eksplisiet. Op dieselfde trant van terugvoermeganismes, word voorgestel dat die betrokke geen, as gevolg van transkripsiefoute, 'n verskeidenheid van boodskapper-RNA(b-RNA)-molekules weergee en dat die boodskapper wat die geskikste proteiene lewer dan, op onbekende wyse, gekeur word vir trutranskripsie na DNA. Die gunstige boodskapper word só vir die nageslag gevestig. Die veelvuldigheid van verwerkte pseudogene by eukariote getuig van 'n erfenis van b-RNAinlastings ten minste in laasgenoemde selle. ${ }^{\text {th }}$ Cairns se verklaring kom daarop neer dat stabilisasie van 'n mutant op die DNA-vlak afhanklik blyk te wees van 'n erkenning van die aanwendbaarheidswaarde van die mutasie. Hierdie uitleg los 'n effens Lamarckistiese smaak in die mond en druis direk in met die hoofdogma van molekulêre genetika wat dit duidelik stel dat, wanneer inligting eers na proteien gevloei het, die kennis nie herwin kan word nie - die vertaling van b-RNA na peptied is ' $n$ eenrigtingproses. ${ }^{67}$ Hierdie stelling het behoue gebly ondanks heelwat verdere ontdekkings rondom b-RNA, byvoorbeeld tru-transkriptases wat RNA na DNA omskep, ${ }^{68,69}$ antisin-RNA wat uitdrukking van gene mag beheer, ${ }^{70}$ ribosieme of RNA-ensieme, ${ }^{71}$ splitslas en die redigering van $b-R N A$ voor vertaling. ${ }^{72,73}$

Of dit nou aanvaar word dat keuring (hoewel onder molekules in plaas van selle of indiwidue) werksaam op lukraak variante (van b-RNA pleks van gene) nou meer Lamarckisties as Darwinisties is, bly die feit staan dat, indien hierdie meganisme van gerigte mutasies juis bewys word, dit 'n radikale uitwerking op biologiese denke gaan meebring.

Cairns ${ }^{74}$ wil hê dat, met die verwerking van biologiese inligting, amper alles moontlik is - volgordes kernsure word gesplitslas, herrangskik, verwerp, opgewek en selfs geredigeer wanneer toestande dit vereis en dit hoort dus binne die vermoëns van bakterieë te wees (wat volgens een siening ${ }^{75}$ net 'n huisvesting vir DNA is) om 'n fenotipe te toets alvorens die oorsaaklike genotipe aanvaar word.

Die reeks eksperimente het wye reaksie uitgelok. $0,44,45,63$, 65, 76-80 Die meeste het die bewering dat die substraat ' $n$ spesifieke invloed op mutasiefrekwensie kan uitoefen versigtig verwerp, en aangevoer dat verskille in oorlewing of groeispoed van mutant en ouer, die resultate met NeoDarwinisme kon versoen. Stahl ${ }^{78}$ het verklaar dat vroegtydige DNA-replikasie'n mutasie na laktosebenutting, wat andersins weens die werking van korreksie-ensieme moontlik 'n kortstondige bestaan sou hê, nou stabiliseer. Die nodige energie sou van kannibalisme en die nuutgevonde laktosesubstraat afkomstig wees. Hierdie verklaring wentel om die feit dat, met doodhonger selle, die allerbelangrike relatiewe spoed van die verskeie stappe betrokke by mutasie, DNA-replikasie en wanaanpassingskorreksie, uit pas met mekaar mag wees. Davis se voorste ${ }^{45}$ het dié van Stahl verder uitgebou: hy wil hê dat transkripsie deur die potensiële substraat (laktose) gemomduseer, onewewigtigheid in die lukraak proses van mutasie skep. Transkripsie vereis skeiding van die DNA-bande en die enkelband-DNA (veral onder omstandighede van uithongering) is muteerbaarder as die dubbelband makker. Die gevolg is 'n toename in frekwensie van kansmutasies, wat dan natuurlik 'n ooreenkomstige toename in moontlike aanwendingsmutasies meebring. Laasgenoemde gee aanleiding tot ooreenstemmende fenotipes wat dan aan klassieke seleksie onderworpe sou wees. Die Davis-uitleg is dus 'n poging om die resultate van bogenoemde eksperimente met die huidige beginsels van molekulêre genetika te versoen.

Hoewel Davis se verklaring ${ }^{45}$ in pas blyk te wees met 'n Neo-Darwinistiese siening, boots sy aanpassingsmutante die begrip van gerigte mutante presies na met die invloed op evolusie: albei sou die toename van aanwendbare fenotipes bevorder. Davis se uitleg verskil van die van Cairns ${ }^{\text {6a }} 74$ in die opsig dat aanwendingsmutante, na sy mening, omgewingsgeïnduseerd maar nie omgewingsgerig is nie.

\section{VERSOENING?}

Bewyse vir 'n verskeidenheid van gerigte mutasies in bakterieë is gevind in alle gevalle waar daarna gesoek is. ${ }^{62}$ Uiteindelik is dit bra moeilik (amper pervers) om nie te wil aanvaar dat 'n voordelige meganisme, wat bakterieë onder selektiewe toestande toelaat om die frekwensie van spesifieke aanwendingsmutante te reguleer, nog nooit in die gang van evolusie gekeur was nie. ${ }^{30,60,74} \mathrm{Neo}$-Darwinisme moes al baie bedreigings trotseer: ${ }^{81}$ daar is die aanslae van neutraliste wat onder andere beweer dat evolusie op molekulêre vlak grotendeels aan die lukraak stroming van allele, en nie natuurlike seleksie nie, te wyte is. ${ }^{82}$

Daar is ook die uitdaging van 'n groep palanteoloë - die onderbrekers of saltasioniste - wat die geleidelikheid van die Darwinistiese verklaring oor die gang van evolusie en die ekstrapolering van mikro- tot makro-evolusie, bevraagteken. ${ }^{10,83}$ Daar is ook dié wat selfs die hoeksteen van die teorie - natuurlike keuring - in twyfel trek (kyk 84, 85).

Tans is dit moontlik dat die meeste bioloë natuurlike seleksie (soos in Neo-Darwinisme vervat) aanvaar as 'n teorie wat vele waarhede inhou. In hierdie verband kan genoem word hoe bevestiging van die Darwinistiese model van vooraanpassingsmutasies ${ }^{14,15}$ tot die uiteindelike ver- 
werping van die instruktiewe teorieë in verband met geinduseerde ensiemvorming ${ }^{86}$ en die antiliggaamrespons, ${ }^{87}$ gelei het.

Neo-Darwinisme se omvang en begrip is gelukkig ruim genoeg om meeste bedreigings te kan akkommodeer sonder om beginsels prys te gee. ${ }^{11}$ Moontlik sal die nuutste dreigement van gerigte mutasies dien om die begrip van oorerflikheid van verworwe eienskappe - alhoewel nie in die tradisionele sin van Lamarck nie, ${ }^{6,45}$ weer in die teorie te vestig en só help om evolusieleer verder te verryk.

\section{LITERATUURVERWYSINGS}

1. Braun, W. (1953). Bacterial genetics (Saunders, Philadelphia) p. 19.

2. Woese, C.R. (1987). Bacterial evolution, Microbiol. Rev., 51, 221 271 .

3. Hall, B.G.(1989). Selection, adaptation and bacterial operons, Genome, $31,265-271$.

4. Braun, W. (1952). Studies on population changes in bacteria and their relation to some general biological problems, Am. Nat., 86, 355-362.

5. Mayr, E. (1978). Evolution, Sci. Am., 239, 39 - 47

6. Lenski, R.E., Slatkin, M. \& Ayala, F.J. (1989). Mutation and selection in bacterial populations: Alternatives to the hypothesis of directed mutations, Proc. Natl. Acad. Sci. USA, 86, $2775-2778$.

7. Jacob, F. \& Wollman, E.L.(1961). Sexuality and the genetics of bacteria (Academic Press, New York) p. 5.

8. Lenski, R.E. (1989). Are some mutations directed? TREE, 4, 148 150.

9. Dobzhansky, T., Ayala, F.J., Stebbins, G.L. \& Valentine, J.W. (1977). Evolution (W.H. Freeman, San Francisco) p. 17.

10. Ho, M.W. \& Saunders, P.T. (1979). Beyond neo-Darwinism - an epigenetic approach to evolution, $J$. theor. Biol., 78, 573-591.

11. Stebbins, G.L. \& Ayala, F.J. (1981). Is a new evolutionary synthesis necessary? Science, 213, $967-971$.

12. Lewin, R. (1980). Evolutionary theory under fire, Science, 210,883 $-887$.

13. Darlington, P.J. (1980). Evolution for naturalists (John Wiley \& Sons, New York) p. 79.

14. Luria, S.E. \& Delbrück, M. (1943). Mutations of bacteria from virus sensitivity to virus resistance, Genetics, 28, 491 - 511

15. Cavalli-Sforza, L.L. \& Lederberg, J. (1956). Isolation of pre-adaptive mutants in bacteria by sib selection, Genetics, 41, $367-381$.

16. Lederberg, J. \& Lederberg, E.M. (1952). Replica plating and indirect selection of bacterial mutants, J. Bacteriol., 63, $399-406$

17. Hinshelwood, C.N. (1946). The chemical kinetics of the bacterial cell (Clarendon press, Oxford)

18. Dean, A.C.R. \& Hinshelwood, C.N. (1957). In Drug resistance in micro-organisms, Wolstenholme, G.E.W. \& O'Connor, C.M. eds. (Churchill, London) p. 4.

19. Hinshelwood, C.N. (1944). Bacterial growth, Biol. Rev., 19, $150-$ 163.

20. Lederberg, J. (1989). Perspectives. Replica plating and indirect se!ection of bacterial mutants: isolation of preadaptive mutants in bacteria by sib selection, Genetics, 121, $395-399$.

21. Luria, S.E. (1947). Recent advances in bacterial genetics, Bact. Rev., $11,1-40$.

22. Woese, C.R., Kandler, O. \& Wheelis, M.L. (1990). Towards a natural system of organisms: Proposal for the domains Archaea, Bacteria and Eucarya, Proc. Natl. Acad. Sci. USA, 87, 4576 - 4579.

23. Knoll, A.H. (1985). The distribution and evolution of microbial life in the late proterozoic era, Ann. Rev. Microbiol. 39, 391 - 417.

24. Calvin, M. (1969). Chemical evolution: molecular evolution towards the origin of living systems on the earth and elsewhere (Clarendon press, Oxford) p. 9.

25. Barghoorn, E.S. \& Schopf, J.W. (1966). Microorganisms three billion years old from the precambrian of South Africa, Science, 152, 758 763.

26. Kandler, O. (1985). In Evolution of prokaryotes FEMS symp. no. 29. Schleifer, K.H. \& Stackebrandt, E. eds. (Academic Press, London) p. 355

27. Wilson, G.S. \& Miles, A. (1975). In Topley and Wilson's principles of bacteriology, virology and immunity, sixthed. vol l. (Edward Arnold, London) p. 511.

28. Orla-Jensen, S. (1909). Die Hauptlinien des natürlichen Bakteriensystems, Zbl. Bakt. II Abt., 22, 305 - 346
29. Kluyver, A.J.\& van Niel, C.B. (1936). Prospects for a natural system of classification of bacteria, Zbl. Bakt. II Abt., 94, 369-403.

30. Van Niel, C.B. (1946). The classification and natural relationships of bacteria, Cold Spr. harb. Symp. quant. Biol., 11, 285-301.

31. Sneath, P.H.A. (1962). In Microbial Classification. Twelfih S.G.M symp., eds. Ainsworth, G.C. \& Sneath, P.H.A. (Cambridge University press, Cambridge) p. 289

32. Swanepoel, J.H. (1991). Bydraes van Darwin se voorgangers tot die ewolusieteorie, S. Afr. Tydskr. Natuurwet. Tegnol., 10, 11 - 17.

33. Badash, L. (1989). The age of the earth debate, Sci. Am., 261, 78-83.

34. Pace, N.R. (1991. Origin of life-facing up to the physical setting, Cell, $65,521-533$.

35. Woese, C.R. (1985). In Evolution of prokaryotes. FEMS symp. no. 29. Schleifer, K.H. \& Stackebrandt, E. eds. (Academic Press, London) p. 1.

36. Fox, G.E., Stackebrandt, E., Hespell, R.B.et al. (1980). The phylogency of prokaryotes, Science, 209, 457-463.

37. Woese, C.R. \& Fox, G.E. (1977). The concept of cellular evolution, J. mol. Evol., 10, 1 - 6

38. Gray, M.W.\&Doolittle, W.F. (1982). Has the endosymbiont hypothesis been proven? Micribiol. Rev., 46, 1 - 42 .

39. Zuckerkandl, E. \& Pauling, L. (1965). Molecules as documents of evolutionary history, J. theor. Biol., 8, 357 - 366 .

40. Olsen, G.J., Lane, D.J., Giovannoni, S.J. \& Stahl, D.A. (1986). Microbial ecology and evolution: a ribosomal RNA approach, Ann. Rev. Microbiol., 40, $337-365$.

41. Woese, C.R. \& Fox, G.E. (1977). Phylogenetic structure of the prokaryotic domain: the primary kingdoms, Proc. Natl. Acad. Sci USA, 74, $5088-5090$.

42. Stackebrandt, E. Woese, C.R.(1981). In Molecularand cellularaspects of microbial evolution. S.G.M. symp. no. 32, Carlile, M.J., Collins, J.F. \& Moseley, B.E.B. eds. (Cambridge University press, Cambridge) p. 1.

43. Stackebrandt, E. (1985). In Evolution of prokaryotes. FEMS symp. no. 29. Schliefer, K.H. \& Stackebrandt, E. eds. (Academic press, London) p. 309.

44. Stahl, F.W. (1990). It smells like a unicorn ..., Nature, 346, 791.

45. Davis, B.D. (1989). Transcriptional bias: a non-Lamarckian mechanism for substrate-induced mutations, Proc. Natl. Acad. Sci. USA, 86, 5005 -5009 .

46. Morgan, T.H. (1926). The theory of the gene (Yale University press, New Haven).

47. Haselkorn, R., Golden, J.W., Lammers, P.J. \& Mulligan, M.E. (1987) Rearrangement of nif genes during cyanobacterial heterocyst differentiation, Phil. trans. R. soc. B., 317, $173-181$.

48. Stragier, P., Kunkel, B., Kroos, L. \& Losick, R. (1989). Chromosomal rearrangement generating a composite gene for a developmental regulatory protein, Science; $243,507-512$.

49. Kunkel, B. (1991). Compartmentalized gene expression during sporulation in Bacillus subtilis, Trends Genet., 7, $167-172$.

50. Lwoff, A. (1953). Lysogeny, Bact. Rev, 17, $269-337$.

51. Trevors, J.T.(1986). Plasmid curing in bacteria, FEMS Microbiol. Rev. $32,149-157$.

52. Shapiro, J.A. (1983). Mobile genetic elements (Academic press, New York) p. 688.

53. Temin, H.M. \& Engels, W. (1985). In Evolutionary theory: paths into the future, Pollard, J.W. ed. (John Wiley \& sons, New York) p. 173

54. Little, J.W. \& Mount, D.W. (1982). The SOS regulatory system of Escherichia coli, Cell, 29, $11-22$

55. Storz, G., Tartaglia, L.A., Farr, S.B. \& Ames, B.N. (1990) Bacterial defenses against oxidative stress, Trends Genet. 6, $363-368$.

56. Suzuki, D.T., Griffiths, A.J.F., Miller, J.H. \& Lewontin, R.C. (1989) An introduction to genetic analysis (W.H. Freeman, New York) p. 417 .

57. Smith, J.M. (1989). Evolutionary genetics (Oxford University press, Oxford) p. 11.

58. Cullis, C.A. (1990). DNA rearrangements in response to environmental stress, Adv. Genet., 28, $73-97$.

59. Shapiro, J.A. (1984). Observations on the formation of clones containing araB-lacZ fusions, Mol. gen. genet., 194, 79-90.

60. Cairns, J., Overbaught, J. \& Miller, S. (1988). The origin of mutants, Nature, 335, $142-145$.

61. Hall, B.G. (1988). Adaptive evolution that requires multiple spontaneous mutations. I. Mutations involving an insertion sequence, Genetics, 120, $887-897$.

62. Hall, B.G. (1990). Spontaneous point mutations that occur more often when advantageous than when neutral, Genetics, 126, 5-16. 
63. Symonds, N. (1989). Anticipatory mutagenesis? Nature, 337, $119-$ 120.

64. Benson, S.A. (1988). Is bacterial evolution random or selective? Nature, 336, $21-22$.

65. Editorial (1988). E. coli-Lamarck's best friend? The Lancet, ii, 807.

66. Darnell, J., Lodish, H. \& Baltimore, D. (1986). Molecular cell biology (Scientific American books, New York) second ed. p. 371.

67. Crick, F.H.C. (1958). On protein synthesis, Symp. Soc. exp. biol., 12 , $138-163$.

68. Baltimore, D. (1970). RNA-dependent DNA polymerase in virions of RNA tumour viruses, Nature, 226, $1209-1211$.

69. Temin, H.M. (1989). Retrons in bacteria, Nature, 339, $254-255$.

70. Green, P.J., Pines, O. \& Issouye, M. (1986). The role of antisense RNA in gene regulation, Ann. Rev. Biochem., 55, $569-597$.

71. Waldrop, M.M. (1989). Catalytic RNA virus wins chemistry Nobel, Science, $245,325$.

72. Simpson, L. (1990). RNA editing - a novel genetic phenomenon? Science, $250,512-513$.

73. Hoffman, M. (1991). RNA editing: what's in a mechanism? Science, $253,136-138$.

74. Cairns, J. (1988). Origin of mutants disputed, Nature, 336, 527-528.

75. Richmond, M.H. (1979). "Cells" and "organisms" as habitat for DNA, Proc. R. Soc. Lond. B, 204, $235-250$.

76. Verskeie skrywers (1988). Origin of mutants disputed, Nature, 336, $525-527$.
77. Lenski, R.E., Slatkin, M. \& Ayala, F.J. (1989). Another alternative to directed mutation, Nature, 337, $123-124$.

78. Stahl, F.W. (1988). A unicorn in the garden, Nature, 335, 112-113.

79. Hall, B.G. (1989). Selection, adaptation and bacterial operons, Genome, 31, $265-270$.

80. Lewin, R. (1988). A heresy in evolutionary biology, Science, $241,1431$.

81. Lewin, R. (1980). Evolutionary theory under fire, Science, 210, 883 -887 .

82. Kimura, M. (1979). The neutral theory of molecularevolution, Sci.Am., $241,98-130$.

83. Eldredge, N.\& Gould, S.J. (1972). In Models in Paleobiology, Schopf, T.J.M. ed. (Freeman, San Francisco) p. 82.

84. Sattler, R. (1986). Biophilosophy (Springer-Verlag, Berlin) p. 181.

85. Gould, S.J. (1980). Is a new and general theory of evolution emerging?, Paleobiology, 6, $119-130$.

86. Monod, J. (1966). Fromenzymatic adaptations to allosteric transitions, Science, $154,475-483$.

87. Lederberg, J. (1959). Genes and antibodies, Science, 129, 1649-1653.

Die volgende twee oorsigartikels wat bogenoemde sienswyse komplementeer, het beskikbaar geraak na die aanbieding van die artikel:

Landman, O.E. (1991). The inheritance of acquired characteristics, Ann. Rev. Genet., 25, 1 - 20.

Drake, J.W.(1991). Spontaneous mutation, Ann. Rev. Genet., 25, 125- 146. 